\title{
Pemanfaatan Kacang Hijau Sebagai Sumber Zat Besi Dalam Upaya Pencegahan Anemia Prakonsepsi
}

\section{Utilization of Green Nuts as a Source of Iron in Prevention Efforts of Preconception Anemia}

\author{
Juhrotun Nisa*, Adevia Maulidya Chikmah, Kharisma Anggra Lorenza, Kiki Rizki \\ Amalia, Tri Agustin \\ Prodi Diploma III Kebidanan Politeknik Harapan Bersama, Kota Tegal, Indonesia \\ *nisa.jn20@gmail.com
}

Riwayat Artikel: Dikirim 15 Oktober 2020; Diterima 19 November 2020; Diterbitkan 30 November 2020

\begin{abstract}
Abstrak
Kelompok risiko tinggi mengalami anemia yaitu pada usia remaja, khususnya remaja putri, hal tersebut dikarenakan kebutuhan absorpsi zat besi memuncak pada umur 14-15 tahun sedangkan remaja putra, mengalami puncak absorpsi zat besi satu atau dua tahun berikutnya. Faktor risiko utama anemia defisiensi besi adalah asupan zat besi yang rendah, penyerapan zat besi yang buruk, dan periode kehidupan ketika kebutuhan akan zat besi tinggi. Fortifikasi makanan merupakan cara terampuh dalam pencegahan defisiensi zat besi. Salah satu makanan yang dapat mencegah zat besi adalah kacang hijau. Mengonsumsi 2 cangkir kacang hijau setiap harinya berarti mengonsumsi 50\% kebutuhan besi setiap hari yaitu $18 \mathrm{mg}$ dan dapat meningkatkan kadar hemoglobin selama 2 minggu. Tujuan PKM ini yaitu memberikan gambaran alternatif makanan dalam peningkatan kadar hemoglobin pada remaja. Metode yang digunakan dalam PKM ini yaitu screening anemia melalui pemeriksaan hemoglobin dan penyuluhan kesehatan pada remaja putri di SMK 1 Kota Tegal. Hasil PKM menunjukkan bahwa terdapat peningkatan pengetahuan remaja tentang anemia, jumlah remaja putri yang mengalami anemia 35\% dari total responden. Zat besi merupakan zat gizi utama yang berperan penting sintesis hemoglobin sehingga kurangnya asupan zat besi yang diperoleh dari bahan makanan menyebabkan kadar hemoglobin menurun.
\end{abstract}

Kata Kunci: Anemia, Remaja Putri, Kacang Hijau

\begin{abstract}
High risk groups experience anemia, namely adolescents, especially young women, this is due to the need for iron absorption peaking at the age of 14-15 years while young men, experiencing peak absorption of iron one or two years later. The main risk factors for iron deficiency anemia are low iron intake, poor absorption of iron, and periods of life when the need for iron is high. Food fortification is the most effective way to prevent iron deficiency. One of the foods that can prevent iron is green beans. Consuming 2 cups of green beans every day means consuming 50\% of the daily requirement of iron, $18 \mathrm{mg}$ and can increase hemoglobin levels for 2 weeks. The purpose of this PKM is to provide an alternative picture of food in increasing hemoglobin levels in adolescents. The method used in this PKM is screening anemia through examination of hemoglobin and health education in young women in SMK 1 Tegal City. PKM results show that there is an increase in adolescent knowledge about anemia, the number of adolescent girls experiencing anemia is 35\% of the total respondents. Iron is the main nutrient that plays an important role in the synthesis of hemoglobin so that the lack of iron intake obtained from food causes hemoglobin levels to decrease.
\end{abstract}

Keywords: Anemia, Young Women, Green Beans

\section{PENDAHULUAN}

Penelitian yang dilakukan oleh Nisa, J., Chikmah, A.M., Zulfiana, E (2019) tentang "Perilaku Konsumsi Sumber Enhancer Dan Inhibitor $\mathrm{Fe}$ dengan Kejadian Anemia Pada Kehamilan" menujukan hasil bahwa kebiasaan konsumsi buah dan sayur sebelum ibu hamil memiliki hubungan yang signifikan dengan kejadian anemia pada kehamilan. Berdasarkan penelitian tersebut maka perlu adanya perhatian terhadap makanan yang dikonsumsi sejak sebelum hamil, salah satunya makanan yang dikonsumsi oleh remaja. memperhatikan 
status gizi calon ibu sejak remaja, diharapkan dapat memutus mata rantai terjadinya anemia pada kehamilan.

Remaja adalah individu kelompok umur 10-19 tahun yang dibagi dalam dua terminasi yaitu remaja awal pada rentang umur 10-14 dan remaja akhir 15-19 tahun (Masthalina, H., Laraeni, Y dan Dahlia, Y.P, 2015). Kelompok risiko tinggi mengalami anemia yaitu pada usia remaja, khususnya remaja putri, hal tersebut dikarenakan kebutuhan absorpsi zat besi memuncak pada umur 14-15 tahun sedangkan remaja putra, mengalami puncak absorpsi zat besi satu atau dua tahun berikutnya (WHO, 2011).

Anemia sendiri merupakan masalah gizi di dunia, khususnya di negara berkembang (WHO, 2008; Milman, 2011). Sekitar 50-80\% anemia di dunia disebabkan kekurangan zat besi (Milman, 2011). Prevalensi anemia pada remaja wanita (usia 15-19 tahun) sebesar 26,5\% dan pada wanita subur sebesar 26,9\% (Depkes RI, 2005). Berdasarkan hasil Riskesdas 2013, proporsi anemia di Indonesia pada kelompok umur 5-14 tahun adalah sebesar 26,4\% (Kemenkes RI, 2014).

Faktor risiko utama anemia defisiensi besi adalah asupan zat besi yang rendah, penyerapan zat besi yang buruk, dan periode kehidupan ketika kebutuhan akan zat besi tinggi seperti pada masa pertumbuhan, kehamilan, dan menyusui, Selain itu kebutuhan zat besi yang tinggi pada remaja putri juga terjadi pada masa menstruasi (WHO, 2008).

Pada masa remaja juga cenderung lebih banyak jajan sembarangan, sehingga fortifikasi pangan merupakan salah satu penanggulangannya. Fortifikasi makanan yang banyak dikonsumsi dan yang diproses secara terpusat merupakan inti pengawasan anemia di berbagai Negara. Fortifikasi makanan merupakan cara terampuh dalam pencegahan defisiensi zat besi (Arisman M, 2007). Salah satu makanan yang dapat mencegah zat besi adalah kacang hijau.
Kacang hijau merupakan salah satu bahan makanan yang mengandung zat-zat yang diperlukan untuk pembentukan sel darah, sehingga dapat mengatasi efek penurunan $\mathrm{Hb}$. Kacang hijau mengandung fitokimia lengkap yang dapat berperan dalam pembentukan sel darah merah dan membantu proses hematopoiesis (Astawan, 2008).

Kandungan zat besi dalam kacang hijau paling banyak terdapat pada embrio dan kulit bijinya. Kandungan zat besi dalam kacang hijau sebanyak $6,7 \mathrm{mg}$ dalam 100 gram kacang hijau. Mengonsumsi 2 cangkir kacang hijau setiap harinya berarti mengonsumsi $50 \%$ kebutuhan besi setiap hari yaitu $18 \mathrm{mg}$ dan dapat meningkatkan kadar hemoglobin selama 2 minggu (Rimawati, dkk., 2018).

Beberapa UMKM di Tegal melakukan fortifikasi kacang hijau, salah satunya berbentuk rempeyek, sehingga kami tertarik untuk melakukan pengabdian kepada masyarakat dalam bentuk 'PKM Pemanfaatan Rempeyek Kacang Hijau sebagai Sumber Zat Besi dalam Upaya Pencegahan Anemia Prakonsepsi'.

\section{METODE}

Sasaran utama dalam kegiatan pengabdian pada masyarakat ini adalah Siswi Kelas X SMK 1 Kota Tegal jurusan tata boga, adapun jumlah siswa yang mengikuti kegiatan ini sebanyak 40 orang ditambah 3 orang dari ekstrakurikuler PMR. Kegiatan pengabdian masyarakat dilaksanakan pada tanggal 5-6 Agustus 2019.

Metode yang dilakukan dalam kegiatan pengabdian kepada masyarakat ini meliputi pemeriksaan hemoglobin darah perifer menggunakan GCU-Hb dan Stik Hb, penyuluhan tentang anemia dan solusinya dan pemberian peyek kacang hijau sebagai alternatif peningkatan kadar $\mathrm{Hb}$ pada siswi yang mengalami anemia. 
Gambar 1.

Alur Kegiatan

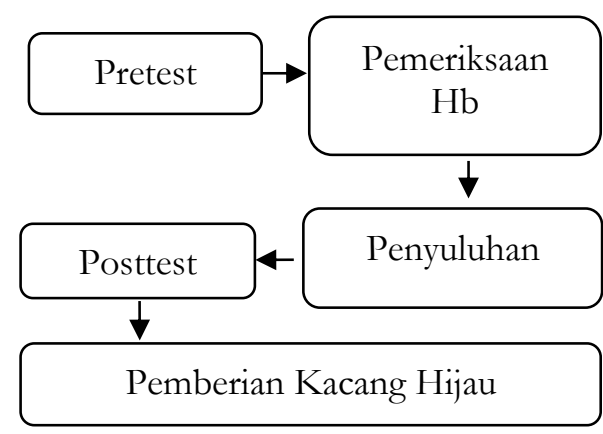

\section{HASIL DAN PEMBAHASAN Hasil}

\section{Pemeriksaan hemoglobin}

Gambar 2.

Pemeriksaan Hemoglobin

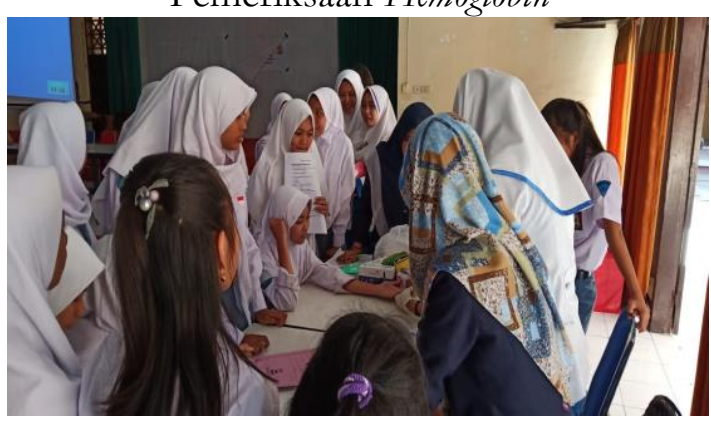

Pemeriksaan hemoglobin dilakukan pada 40 orang remaja putri di SMK 1 Kota Tegal, responden pada awalnya merasa takut untuk dilakukan pemeriksaan hemoglobin sehingga tim pengabdian masyarakat perlu melakukan pendekatan dan motivasi sampai responden mau dilakukan pemeriksaan, adapun hasil pemeriksaan tersebut sebagai berikut:

Tabel 1.

Gambaran Hasil Pemeriksaan Hemoglobin pada Remaja Putri di SMK 1 Kota Tegal

\begin{tabular}{|l|l|c|c|}
\hline No. & \multicolumn{1}{|c|}{ Kriteria } & $\mathbf{F}$ & $\mathbf{\%}$ \\
\hline 1 & Anemia & 14 & $35 \%$ \\
\hline 2 & $\begin{array}{l}\text { Tidak } \\
\text { Anemia }\end{array}$ & 14 & $65 \%$ \\
\hline
\end{tabular}

Dari tabel 1 diketahui bahwa remaja putri di SMK 1 Kota Tegal yang mengalami anemia sebanyak $35 \%$, sedangkan $65 \%$ lainnya memiliki kadar hemoglobin yang normal.

\section{Penyuluhan}

Penyuluhan dilakukan sebagai upaya peningkatan pengetahuan remaja putri di SMK 1 Kota Tegal tentang anemia dan solusinya. Remaja Putri di SMK 1 Kota Tegal sebagian besar tertarik mengikuti kegiatan penyuluhan tersebut dikarenakan mereka belum pernah mendapatkan materi tersebut.

Gambar 3.

Pemberian Pendidikan Kesehatan

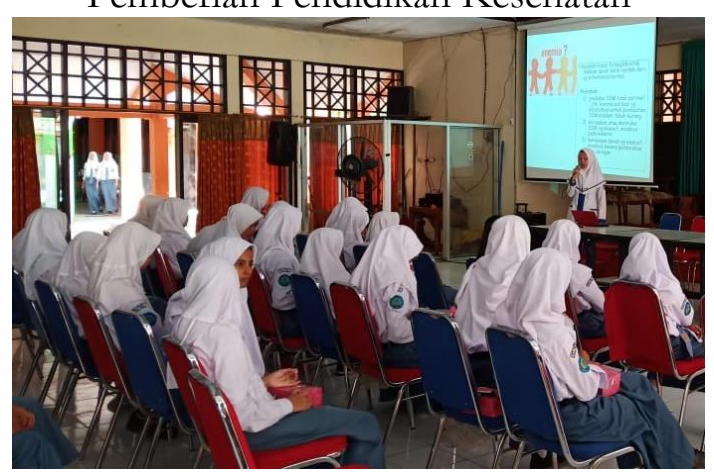

\section{Pemberian Peyek Kacang Hijau}

Pemberian peyek kacang hijau dilakukan sebagai upaya alternatif pengganti tablet besi. Adapun remaja putri yang diberikan peyek kacang hijau adalah mereka yang mengalami anemia yaitu sebanyak 14 responden. Remaja Putri di SMK 1 Kota Tegal pada dasarnya sudah sering mendapatkan tablet besi dari Dinas Kesehatan Kota Tegal yang dikonsumsi pada hari Jumat setiap minggunya, akan tetapi banyak remaja putri yang mengeluhkan bahwa tablet besi tidak enak dikonsumsi dan efeknya sulit buang air besar, sehingga terkadang tablet besi tersebut enggan dikonsumsi. Berdasarkan permasalahan tersebut maka Prodi DIII Kebidanan membuat alternatif untuk meningkatkan kadar hemoglobin pada remaja putri di SMK 1 Kota Tegal melalui pemberian kacang hijau. 
Gambar 4.

Pre-test-Post-test

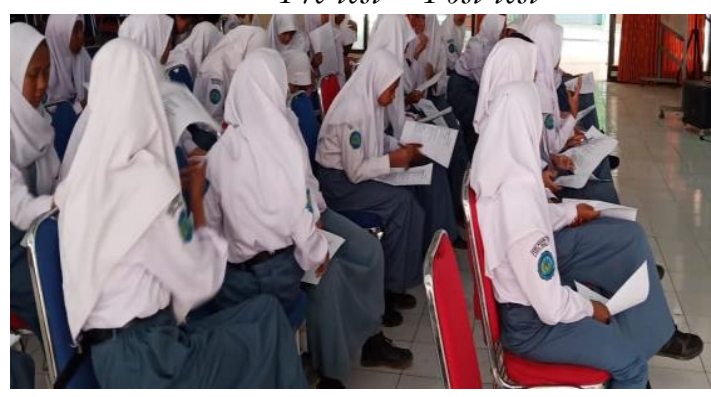

4. Pengetahuan Remaja Putri

Untuk mengetahui pengetahuan awal remaja putri di SMK 1 Kota Tegal dilakukan pemberian kuesioner awal tentang anemia dan untuk mengetahui keberhasilan penyuluhan Prodi DIII Kebidanan Politeknik Harapan Bersama juga melakukan evaluasi melalui pengisian kuesioner tentang pengetahuan anemia. Adapun hasilnya sebagai berikut:

Tabel 2.

Gambaran Pengetahuan Remaja Putri tentang Anemia di SMK 1 Kota Tegal

\begin{tabular}{|l|l|c|c|c|}
\hline \multirow{2}{*}{ No. } & \multirow{2}{*}{ Kriteria } & \multicolumn{3}{|c|}{ Tingkat Pengetahuan } \\
\cline { 3 - 5 } & & Baik & Cukup & Kurang \\
\hline 1. & Pre-test & -6 & 15 & 19 \\
\hline 2. & Post-test & 20 & 17 & 3 \\
\hline
\end{tabular}

Berdasarkan tabel 4.2 di atas bahwa pengetahuan remaja putri di SMK 1 Kota Tegal sebelum dilakukan penyuluhan tentang anemia sebagian besar memiliki pengetahuan kurang sebanyak 19 orang, pengetahuan cukup sebanyak 15 orang dan pengetahuan baik sebanyak 6 orang, sedangkan tingkat pengetahuan setelah dilakukan penyuluhan mengalami peningkatan yaitu responden dengan tingkat pengetahuan baik sebanyak 20 orang, pengetahuan cukup sebanyak 17 orang dan pengetahuan kurang sebanyak 3 orang.

\section{Pembahasan}

Anemia merupakan masalah kesehatan masyarakat di seluruh dunia (Pratiwi, 2016). Menurut data WHO secara global, kasus anemia mempengaruhi 1,62 miliar orang atau sesuai dengan $24,8 \%$ dari populasi. Berdasarkan data Riset Kesehatan Dasar (Riskesdas) 2013 terdapat 21,7\% penduduk dengan kadar hemoglobin yang kurang dari batas normal dengan proporsi $20,6 \%$ di perkotaan dan $22,8 \%$ di pedesaan serta $18,4 \%$ laki-laki dan $23,9 \%$ perempuan. Berdasarkan kelompok umur, 28,1\% pada balita dengan kadar hemoglobin kurang dari $11,0 \mathrm{~g} / \mathrm{dL}$, anak usia 5-14 tahun (Hb kurang dari $12,0 \mathrm{~g} / \mathrm{dL}$ ) sebesar $26,4 \%$, anak usia 15 24 (Hb kurang dari 12,0 g/dL) 18,4\%, dan pada wanita hamil $37,1 \%$. Sementara itu untuk prevalensi anemia di wilayah Provinsi Jawa Tengah berada pada persentase 57,7\% dengan ambang batas masalah anemia sebagai masalah kesehatan masyarakat lebih dari $20 \%$.

Hasil pengabdian kepada masyarakat yang dilakukan di SMK 1 Kota Tegal pada 40 responden menunjukkan hasil bahwa dari 35\% dari para responden anemia. Hal tersebut menunjukkan bahwa jumlah remaja yang anemia memiliki persentase yang lebih kecil dibandingkan yang tidak anemia. Hal tersebut sejalan dengan penelitian yang dilakukan oleh Sriningrat, Yuliyanti dan Ani (2019) yang menunjukkan bahwa dari 74 responden yang mengalami anemia sebesar $45,9 \%$, sedangkan penelitian yang dilakukan oleh Aulia dkk. (2017) menunjukkan bahwa $56 \%$ dari 100 remaja putri yang menjadi responden $56 \%$ mengalami anemia.

Zat besi merupakan zat gizi utama yang berperan penting sintesis hemoglobin sehingga kurangnya asupan zat besi yang diperoleh dari bahan makanan menyebabkan kadar hemoglobin menurun. Selain itu, jumlah zat besi dalam tubuh juga dipengaruhi oleh faktor penghambat penyerapan zat besi. Faktor penghambat penyerapan zat besi banyak terdapat dalam bahan makanan seperti fitat yang terkandung dalam kacang-kacangan, bijibijian; posfitin yang terkandung dalam kuning telur; oksalat yang terkandung dalam sayuran; dan tannin yang terkandung dalam teh dan kopi. Di samping faktor penghambat, terdapat juga faktor pemacu penyerapan besi yaitu vitamin C. Suasana 
asam dan sifat reduktor vitamin $\mathrm{C}$ diperlukan dalam penyerapan zat besi, di mana penyerapan zat besi akan meningkat empat kali lipat dengan bantuan vitamin C.

Berdasarkan hasil PKM yang dilakukan menunjukkan adanya perubahan pengetahuan di mana pengetahuan baik dari 6 menjadi 20, pengetahuan cukup dari 15 menjadi 17 dan pengetahuan kurang dari 19 menjadi 3. Hal ini sejalan dengan penelitiannya Wikanjaya dan Sungkar (2014) mengatakan bahwa penyuluhan efektif dalam meningkatkan pengetahuan. Selain itu Penelitian yang dilakukan oleh Ichsan, Rosyidah, Fitra (2013) menunjukkan bahwa terdapat pengaruh penyuluhan terhadap peningkatan pengetahuan. Keadaan ini dapat menggambarkan bahwa penyuluhan kesehatan merupakan suatu kegiatan yang dapat mempengaruhi perubahan responden meliputi pengetahuan.

Pemberian peyek kacang hijau dianggap sebagai upaya untuk meningkatkan kadar hemoglobin sesuai penelitian yang dilakukan oleh Faridah dan Indraswari (2017) menunjukkan bahwa ada pengaruh kacang hijau terhadap peningkatan kadar $\mathrm{Hb}$ pada remaja putri yang mengalami anemia dan penelitian Yang dilakukan Retnorini, Widatiningsih, Masini (2017) mengatakan bahwa ada pengaruh pemberian zat besi dan sari kacang hijau u terhadap kadar hemoglobin pada ibu hamil.

Kacang hijau mengandung zat besi sebanyak 2,25 mg dalam setiap setengah cangkir kacang hijau. Kacang hijau juga mengandung fitat sebesar 2,19\%. Fitat dapat menghambat penyerapan zat besi sehingga dianjurkan untuk merendam kacang hijau sebelum mengolahnya. Pengolahan kacang hijau melalui perendaman sebelumnya bertujuan untuk memudahkan penyerapan zat besi yang diperlukan untuk maturasi selsel darah (Heltty, 2008) Biji kacang hijau yang telah direbus atau diolah dan kemudian dikonsumsi mempunyai daya cerna yang tinggi dan rendah daya flatulensinya. Hemaglutinin dapat menggumpalkan sel darah merah dan bersifat toksik.

\section{KESIMPULAN}

Kegiatan Pengabdian Masyarakat ini meningkatkan pengetahuan remaja putri tentang anemia dan solusi alternatifnya. Melalui kegiatan pengabdian ini juga dilakukan skrining pada remaja dengan menemukan remaja yang mengalami anemia sebanyak 35\%, selain itu remaja putri yang mengalami anemia telah diberikan rempeyek kacang hijau sebagai bahan alternatif pengganti tablet besi lebih diterima remaja putri dibandingkan tablet besi.

Perlu dibentuk kader anemia pada kegiatan PMR yang bertugas melakukan skrining anemia pada remaja putri dan perlunya remaja putri untuk lebih memperhatikan konsumsi jajanannya terutama bagi mereka yang mengalami anemia.

\section{DAFTAR PUSTAKA}

Akbar. (2015). Aneka Tanaman Apotek Hidup di Sekitar Kita. Jakarta : One Book.

Arisman M. (2007). Buku Ajar Ilmu Gizi dalam Kebidupan. Jakarta: EGC.

Astawan. (2009). Sehat dengan Hidangan Kacang dan Biji-bijian. Depok: Penebaran Swadaya.

Departemen kesehatan RI. (2005). Giæi dalam Angka. Jakarta: Departemen Kesehatan.

Dinas Kesehatan Provinsi Jawa Tengah. (2009). Profil Kesehatan Jawa Tengah. Semarang.

Direktur Bina Gizi. (2015). Rencana Aksi Pembinaan Gizi Masyarakat (RAPGM) Tahun 2010-2014 [Internet]. Departemen Kesehatan Republik Indonesia; Tersedia di: http://www.gizikia.depkes.go.id/ter bitan/rencana-aksi-pembinaangizimasyarakat-rapgm-tahun-20102014/?print.pdf. 
Ghea Yanna Aulia, Ari Udiyono, Lintang Dian Saraswati, M. Sakundarno Adi. (2017). Gambaran Status Anemia Pada Remaja Putri Di Wilayah Pegunungan Dan Pesisir Pantai (Studi Di SMP Negeri Kecamatan Getasan Dan Semarang Barat). Artikel jurnal. Jurnal Kesehatan Masyarakat (e-Journal). Volume 5, Nomor 1, Januari 2017 (ISSN: 2356-3346). http://ejournal.s1.undip.ac.id/index. $\mathrm{php} / \mathrm{jkm}$.

Gusti Agung Ayu Sriningrat, Putu Cintya Denny Yuliyatni, Luh Seri Ani. (2019). Prevalensi Anemia Pada Remaja Putri Di Kota Denpasar I. Artikel jurnal. E-JURNAL MEDIKA, 8(2), Februari, 2019. https://ojs.unud.ac.id/index.php/eu $\underline{m}$.

Ichsan, Rosyidah, Fitra. (2013). Pengaruh Penyuluhan Terhadap Peningkatan Pengetahuan Kesehatan Reproduksi Remaja di SMA PGRI 3 Purwakarta. Naskah Publikasi. FK-UMS; Surakarta.

Kemenkes RI. (2013). Riset Kesehatan Dasar. Jakarta: Kementerian Kesehatan Republik Indonesia.

Kementerian Kesehatan RI. (2014). Riset Kesehatan Dasar 2013. Jakarta: Kementerian Kesehatan Republik Indonesia.

Masthalina, H. , Laraeni, Y dan Dahlia, Y.P. (2015). Pola Konsumsi (Faktor Inhibitor Dan Enhancer $\mathrm{Fe}$ ) Terhadap Status Anemia Remaja Putri. KEMAS 11 (1), 80-86.
Milman, N. (2011). Anemia still a major health problem in many parts of the world! Review Article. Ann Hematol, 90:369-377.

Muchtadi. (2009). Gizi Anti Penuaan Dini. Bandung: CV. Alfabet 